\title{
IMPLEMENTATION OF THE PARIS AGREEMENT IN POLAND. THEORY AND PRACTICE
}

\author{
Ewa Radecka*, Filip Nawrot ${ }^{* *}$
}

\begin{abstract}
The main aim of this paper is to describe the legal instruments of climate protection in Poland. This issue is significant, because for several decades, climate changes and climate protection have been the object of legal regulation, both international, European and domestic. The conducted analysis concerns two main legal acts: the Act of 9 June 2011 - the Geological and Mining Law as regards CCS, and the Act of 20 February 2015 on Renewable energy (including, to a certain extent, regulations of the Act of 20 May 2016 on Investments in wind power plants) as well as other provisions relating to environmental protection. The paper closes with an evaluation of the present regulations and formulation of de lege ferenda proposals.
\end{abstract}

Key words: climate protection in Poland, geological storage of carbon dioxide, CCS, Renewable energy sources, spatial planning

\section{INTRODUCTION}

Climate change is a fact that we cannot discuss, the only thing we can analyse are provisions related to protection of the climate and more gener-

PhD, Assistant professor, Faculty of Law and Administration, Institute of Law, University of Silesia in Katowice; ewa.olejarczyk@us.edu.pl

** M. A., PhD student, Faculty of Law and Administration, Institute of Law, University of Silesia in Katowice; fnawrot@us.edu.pl 
ally, environmental protection. This paper will describe Polish provisions, which are regulating climate protection and Authors will evaluate these regulations in the scope of both international and European law.

In public international law, the key climate protection instrument is the United Nations Framework Convention on Climate Change, drawn up in New York on 9 May 1992. The Convention is quite general in nature. While it does lay down certain commitments for the Parties (Article 4 of the Convention), they mostly concern information, promotion, and planning. The Convention offers hardly any "hard" instruments, whose implementation could later be subject to evaluation in terms of their effectiveness.

The objectives laid down in the Convention are to be achieved primarily through applicable protocols (established pursuant to Article 17 of the Convention), and more specifically - through the Kyoto Protocol to the United Nations Convention on Climate Change adopted in 1997, which entered into force on 16 February $2005^{1}$. Under the Protocol, the States-Parties committed to reducing their overall emissions of greenhouse gases by negotiated levels laid down in the annex to the Protocol (at least 5\% below 1990 levels). In the case of a deficit or surplus of allowances, the signatories committed to selling or buying allowances from other states.

Lack of possibilities (especially political ones) for signing of a new protocol to the Convention meant that it became necessary to search for another formula for a multilateral agreement that would make it possible to integrate measures intended to reduce greenhouse emissions. This is why, on 12 December 2015, the Paris Agreement to the United Nations Framework Convention on Climate Change, drawn up in New York on 19 May 1992, was signed. The Agreement details measures intended to contribute to stopping global warming at a level "much below $2^{\circ} \mathrm{C}$ " (up to 2020).

By adopting the act of 6 October 2016, the Sejm of the Republic of Poland expressed its consent to the ratification of the Paris Agreement to the United Nations Framework Convention on Climate Change, drawn

1 The Kyoto Protocol entered into force on 16 February 2005 and formally expired on 31 December 2012. However, the European Union, Norway, Iceland, Monaco, Switzerland and Liechtenstein (EEA countries) undertook to extend their commitments under the Treaty until the year 2020 . 
up in New York on 19 May 1992, adopted in Paris on 12 December $2015^{2}$. This was followed by the President of the Republic of Poland ratifying the Agreement. The next day, the ratification documents were deposited in the UN headquarters in New York.

The States-Parties agreed that measures in this regard must be undertaken as the threat of irreversible changes such as disappearance of small island states, destruction of coral reefs, and Greenland glaciers melting is real.

The Paris Agreement does not provide proposals for specific instruments (mechanisms) for climate protection. Instead, it draws on voluntary, not subject to penalty, implementation of emission reduction commitments based on auto control. The Parties aim to reach global peaking of greenhouse gas emissions as soon as possible and to undertake rapid reductions thereafter in accordance with best available science, so as to achieve a balance between anthropogenic emissions by sources and removal by sinks of greenhouse gases.

Furthermore, the Agreement does not lay down quantitative commitments of the respective states as regards the reduction of greenhouse gas emissions. In lieu of those, it provides for information commitments (verification every five years of the nationally determined contribution to fight against climate change in terms of the effectiveness of undertaken measures). This applies to measures submitted as part of so-called intended nationally determined contributions (INDC).

Measures undertaken by the respective states should proceed along two lines: as measures intended to reduce carbon dioxide emissions, and as measures conducive to absorption of $\mathrm{CO} 2$. The former include introduction of new technologies or increasing the share of renewable energy sources in the energy mix. Meanwhile, the latter may involve absorption of carbon dioxide by forests or soil, which in turn will contribute to countering the effects of global problems such as migrations, food safety, access to good quality water and air, or protection of biological diversity ${ }^{3}$.

2 Journal of Laws, item 1631.

3 See, in greater detail, Janina Ciechanowicz McLean, "Prawne problemy umów międzynarodowych z zakresu ochrony klimatu” [„Legal issues in international agreements concerning climate protection”], Gdańskie Studia Prawnicze XXXVII(2016): 107-120. 


\section{EXAMPLES OF THE IMPLEMENTATION \\ OF THE PARIS AGREEMENT IN POLAND}

Poland's government plans to implement the Paris Agreement predominantly not by reducing carbon emissions but by boosting carbon absorption. This is to be achieved by increasing the forestation of Poland, a task to be carried out by so-called Forest Carbon Farms, a project utilising unique research centred on identification of forestry resources and the volume of absorbed carbon dioxide in all reservoirs of the forest ecosystem, including the tree layer, shrub layer, ground cover and soil.

The Forest Carbon Farms pilot project, carried out by State Forests, is scheduled to run until 2026. The planned outcome is intensification of forest management leading to additional accumulation of organic coal. This is to be achieved by additional tree plantings, stand renewal, naturally regenerated stand, or introduction of fast-growing species. In addition to forests, the pilot program is also supposed to encompass peat bogs and wetlands, which are natural reservoirs of carbon dioxide ${ }^{4}$.

At present it is difficult to review the effectiveness of the primary method of implementation of the Paris Agreement adopted by Poland for neither the project's details nor its dimensions are known. It is to be hoped that the first outcomes can be evaluated after the end of the pilot project, which will happen in approximately 8 years.

Poland has also undertaken to implement the Paris Agreement through two categories of measures. The first one is implementation of new technologies, which most likely refers to fuel burning technologies and other economic activities. The other category concerns increasing the share of renewable energy sources in the energy mix, which applies in particular to the development of distributed power engineering based on renewable energy sources. It is supposed to deliver specific economic benefits and boost Poland's energy security.

4 About Forest Carbon Farms vide: http://projekty-rozwojowe.lasy.gov.pl/projektyrozwojowe/-/asset_publisher/7PcENrBXIBZJ/content/lesne-gospodarstwa-weglowe, http://www.ebiomasa.pl/lesnictwo-news/item/2479-energa-wspiera-lesne-gospodarstwaweglowe; https://niezalezna.pl/206274-lesne-gospodarstwa-weglowe-swiat-powinien-sie-tymzainteresowac. See also critical view: https://oko.press/wunderwaffe-polskiej-ekologii-lesnegospodarstwa-weglowe-nas-nie-uratuja/ July 12, 2019. 
Regretfully, Poland's commitments referred to above are essentially political in nature and do not translate into corresponding legislative initiatives. Notwithstanding that, they are still discussed in government documents at a high level of generality, with virtually no specifics provided.

As regards Poland's solutions that can be classified as potentially contributing to the Paris Agreement, the two central ones are as follows. The first one is introduction, on a very limited basis, of technologies for geological storage of carbon dioxide (CCS). The other one involves regulation of construction and operation of renewable energy sources installations. These solutions were introduced in the aftermath of earlier climate agreements and the so-called energy package adopted in the European Union.

\section{GEOLOGICAL STORAGE OF CARBON DIOXIDE}

The climate package 2020 encompasses several acts governing various measures intended to mitigate the greenhouse effect. These include: Directive 2009/28/EC of the European Parliament and of the Council of 23 April 2009 on the promotion of the use of energy from renewable sources and amending and subsequently repealing Directives 2001/77/EC and 2003/30/EC 5 , Directive 2009/31/EC of the European Parliament and of the Council of 23 April 2009 on the geological storage of carbon dioxide and amending Council Directive 85/337/EEC, European Parliament and Council Directives 2000/60/EC, 2001/80/EC, 2004/35/EC, 2006/12/EC, 2008/1/EC and Regulation (EC) No 1013/2006 ${ }^{6}$ and Decision No 406/2009/EC of the European Parliament and of the Council of 23 April 2009 on the effort of Member States to reduce their greenhouse gas emissions to meet the Community's greenhouse gas emission reduction commitments up to $2020^{7}$.

When it comes to the CCS Directive implementation, Poland did it with a delay. Article 39 of the CCS Directive imposes on the Member States the obligation to comply with the Directive by 25 June 2011. Po-

\footnotetext{
5 OJ L 140, 5.6.2009, pp. 16-62, further referred to as the RES Directive.

OJ L 140, 5.6.2009, pp. 114-135, further referred to as the CCS Directive.

OJ L 140, 5.6.2009, pp. 136-148, further referred to as the non-ETS Decision.
} 
land implemented it later, when the Act of 27 September 2013 amending the Geological and mining law act and some other acts ${ }^{8}$ entered into force. The aforementioned amendment added provisions related to carbon storage and capture to the Act of 9 June 2011 Geological and mining law, thus making it not necessary to enact new laws in this regard'. This solution is definitely a welcome step as it fosters legal clarity and does not lead to adoption of further, redundant, legal acts. What is more, the issue of geological sequestration of carbon dioxide is similar to other types of activity undertaken pursuant to Geological and mining law, spelled out in article 1 thereof $^{10}$.

As a preliminary point, it should be stressed that the amendment to the Geological and mining law did not introduce the possibility of "industrial" use of CCS in Poland; instead, it only allowed for the development of "demo" installations for capture and storage of carbon dioxide. As defined in the article 1 item 3 GML, a demonstration project for capture and storage of carbon dioxide is a project for the capture, transmission and underground storage of carbon dioxide, meeting the criteria for demonstration projects set forth in the Commission Decision No. 2010/670/EU) of 3 November 2010 laying down criteria and measures for the financing of commercial demonstration projects that aim at the environmentally safe capture and geological storage of CO 2 as well as demonstration projects of innovative renewable energy technologies under the scheme for greenhouse gas emission allowance trading within the Community established by Directive 2003/87/EC of the European Parliament and of the Council (OJ L 290, 6.11.2010, p. 39) which is implemented for the purpose of verifying:

8 Official Journal of Laws 2013, item 1238, as amended, further referred to as CCS amendment.

9 See more: Grzegorz Dobrowolski, "Prawne zasady podejmowania i prowadzenia działalności w zakresie bezpiecznego geologicznego składowania dwutlenku węgla” ["Legal rules for taking up and pursuit of the activity of safe geological storage of carbon dioxide"], In: Prawna regulacja geologii i górnictwa w Polsce, Czechach i na Słowacji. Wybrane zagadnienia, ed. Grzegorz Dobrowolski, Gabriel Radecki, Katowice: Grupa Informax, 2014, 240-252.

10 Grzegorz Dobrowolski, “Prawne ...”, 245-246. 
1) the effectiveness and usefulness of application of the technology of carbon dioxide capture and storage in the scope of carbon dioxide emission limitation;

2) the safety of application of the technology of carbon dioxide capture and storage for human health and life and for the environment;

3) the need and grounds for admitting to application the technology of carbon dioxide capture and storage on an industrial scale ${ }^{11}$.

When expanding the subjective scope of the GML, the legislator changed the general principles of the use of geological resources. It mainly applies to the plant, mining land, mining area, prospecting or exploring. But it also introduced new concepts, for example:

- corrective actions (article 6 item 1 point 1a GML) - are the actions undertaken in order to:

a) correct or eliminate irregularities in the process of injection or storage of carbon dioxide or in the underground carbon dioxide storage complex which imply the risk of a carbon dioxide leakage occurring or risk to the environment, as well as human health and life;

b) stop leakage of carbon dioxide so as to prevent or stop the release of carbon dioxide out of the underground carbon dioxide storage complex ${ }^{12}$.

- underground carbon dioxide storage complex (article 6 item 1 point 2a GML) - is the underground carbon dioxide storage site and surrounding geological formations which can have an effect on underground carbon dioxide storage integrity and security ${ }^{13}$;

- underground carbon dioxide storage site (article 6 item 1 point 5a GML) - is a part of rock mass of specific volume used for the purpose of permanent carbon dioxide storage, connected with the surface injection facility ${ }^{14}$.

11 Aleksander Lipiński, "Komentarz do art. 1 - 2 ustawy z dnia 9 czerwca 2011 r. Prawo geologiczne i górnicze ["Commentary to the articles $1-2$ of the Act of 9 June 2011 Geological and mining law”], Prawne Problemy Górnictwa i Ochrony Środowiska 1(2016) [Legal Problems of Mining and Environmental Protection 2(2016)]: 34.

12 Grzegorz Dobrowolski, "Prawne ...", 246-247.

13 Ibidem.

14 Ibidem. 
It is useful at this point to note that geological storage of carbon dioxide is possible only at significant depths (over 800 metres). It is connected with physical characteristics of carbon dioxide which can change depending on pressure and temperature ${ }^{15}$.

As far as the regulation of undertaking and conducting of business activity with regard to CCS is concerned, the amended Geological and mining law provides two regulation instruments, namely a licence to search for or examine an underground carbon dioxide storage facility and a licence for underground storage of carbon dioxide ${ }^{16}$. Both licences are granted by the Minister of the Environment, in agreement with relevant authorities, both at a central and local level. Provisions concerning these licences make it clear that conducting business activity focused on searching for or examining an underground carbon dioxide storage facility or underground storage of carbon dioxide for purposes other than carrying out a demonstration project for capture and storage of $\mathrm{CO} 2$ is forbidden ${ }^{17}$. The licensing procedure is described in detail in the Geological and mining law ${ }^{18}$. Special attention in this regard should be given to provisions concerning cooperation with the European Commission in the awarding of these licences.

Summing up this part of the analysis, it must be pointed out that while the CCS technology is an innovative idea for dealing with $\mathrm{CO} 2$, it

15 Grzegorz Dobrowolski, Gabriel Radecki, In: Zrównoważony rozwój jako czynnik determinujący prawne podstawy zarządzania geologicznymi zasobami środowiska [Sustainable development as a defining factor of management of geological resources], ed. Grzegorz Dobrowolski, Katowice: Agencja Reklamowa TOP, 2016, 208; Józef Dubiński, Jan Wachowicz, Aleksandra Koteras, "Podziemne składowanie dwutlenku węgla - możliwość wykorzystania technologii CCS w polskich uwarunkowaniach" ["Underground carbon dioxide storage - possibilities of using the CCS technology in Polish conditions"], Górnictwo i Geologia [Mining and Geology] 5(2010): 11-16.

16 Grzegorz Dobrowolski, Gabriel Radecki, In: Zrównoważony..., 210; Grzegorz Dobrowolski, Aleksander Lipiński, Ryszard Mikosz, Gabriel Radecki, Gospodarowanie geologicznymi zasobami środowiska w świetle zasady zrównoważonego rozwoju. Zagadnienia prawne [Management of the geological resources in the light of the principle of sustainable development. Legal issues], Katowice: Wydawnictwo Uniwersytetu Śląskiego, 2018, 212.

17 Grzegorz Dobrowolski, "Prawne ...", 24.

18 See more: Grzegorz Dobrowolski, Gabriel Radecki, In: "Zrównoważony...", 210-216; Grzegorz Dobrowolski, Aleksander Lipiński, Ryszard Mikosz, Gabriel Radecki, "Gospodarowanie...", 212-218. 
is yet to find extensive practical application. It appears, however, that the use of this technology is bound to increase in the future, although de lege lata the introduction of provisions concerning carbon capture and storage was justified by the need for some entrepreneurs to fulfil their obligations as regards CCS, for instance due to the fact that they obtained funding from the EU.

\section{RENEWABLE ENERGY SOURCES}

Issues related to renewable energy sources are of particular importance, not just in the context of environmental protection or sustainable development, but also energy safety of the state. It might appear that Poland, as a country largely dependent on fossil fuels, should strive to diversify its sources of energy and expand the use of the so-called green energy. A question remains, however, whether the solutions adopted by the legislature facilitate or hinder the development of RES ${ }^{19}$.

Hitherto the most important domestic legislation regulating this mat$\operatorname{ter}^{20}$ (albeit in rather general terms) was the Energy Law Act of 10 April

19 The matter is currently incredibly popular e.g. due to the upcoming deadline for fulfilling international commitments entered into. One of these is Poland having to reach a minimum $15 \%$ share of renewable energy sources in the gross final energy consumption, including a minimum $10 \%$ share of renewable energy used in transportation (see art. 3 RES Directive) by the year 2020.

20 As a side note, other documents directly connected with this issue are: the Energy Policy of Poland until 2030, adopted by the Council of Ministers on 10 November 2009 (Annex to Resolution of the Council of Ministers no. 202/2009 of 10 November 2009, July 29, 2019 http://www.mg.gov.pl/files/upload/8134/Polityka\%20energetyczna\%20ost. pdf) or the National Renewable Action Plan for Poland, including its supplement of 2 December 2011 (July 29, 2019 http://www.mg.gov.pl/files/upload/12326/uzupełnienie\%20 KPD_www.pdf). Furthermore, it should be pointed out that as of the date of submission of this article for print, works on the draft version of the Energy Policy of Poland until 2040 were in progress (July 29, 2019 https://www.gov.pl/web/energia/polityka-energetyczna-polski-do-2040-r-zapraszamy-do-konsultacji1). Interestingly, the draft envisages ambitious plans in the area of energy policy. More specifically, Poland should reach the $21 \%$ share of renewable energy sources in the final energy consumption by 2030, whilst at the same time decreasing the use of wind turbines on land and increasing their use on the sea. By 2040, the key energy suppliers in the renewable energy sources will be photovoltaic sys- 
$1997^{21}$. Currently the issues in question are discussed in more detail by the following acts: Act of 20 February 2015 on Renewable energy sources and, to some extent, Act of 20 May 2016 on Investments in wind power plants. As a side note, it should be added that the former has already been amended 20 times, which is certainly not conducive to stability and legal certainty of investors.

The explanatory statement to the Act on Renewable Energy Sources points out that the reason for undertaking legislative works on this act was to ensure ongoing development of energy economy and at the same time increase energy safety and facilitate environmental protection. Furthermore, commencement of works on the Act was motivated by the need to adapt the Polish legal system to European Union policy, which considers supporting renewable energy sources highly important and necessary ${ }^{22}$.

We shall now move on to selected issues as regards wind farms, as they are very popular in Poland and, according to the Energy Regulatory Office statistics, have the greatest share in the power generated by RES power plants and CHP plants in Poland.

The 2016 Act was supposed to help prevent a number of problems related to the location of wind farms, such as taking up areas characterised by best quality soils, placement of the farms in too close vicinity of buildings and resultant negative impact on the landscape.

The Act regulates three areas by introducing: 1) the legal definition of a wind farm, 2) the so-called distance rule, and 3) a rule governing the location of wind farms based on local zoning plans.

A wind farm is defined as a structure, within the meaning of provisions of building law, consisting of foundations, a tower, and technical elements, with an output power greater than the output power of a micro installa-

tems and sea-based wind farms. The forecasted energy sources in 2040 are as follows: 32\% coal, 34\% renewable energy sources and waste materials, $16 \%$ gas, and as much as $18 \%$ (sic!) atomic energy (July 29, 2019 https://wysokienapiecie.pl/14959-polityka-energetyczna-2040-pobozne-zyczenia-w-sprawie-wegla-atomu/).

21 Official Journal of Laws 2019, item 755, as amended, consolidated text.

22 See e.g. point 5 of the preamble RES Directive. It highlights the role of the development of energy coming from renewable energy sources, intended to minimize the European Community's dependence on energy imports. 
tion, as defined in the Renewable energy sources act, i.e. more than $40 \mathrm{~kW}$ of total installed electrical capacity.

The premise underlying this act was the introduction of the so-called distance rule ${ }^{23}$, the adoption of which was supposed to be an answer to protests of various social groups caused by the location of wind farms on the ground. The protests concerned both issues related to health (noise emissions), environment (threats as regards e.g. nature conservation forms ${ }^{24}$ ), and aesthetics (in the context of landscapes). There are two aspects to the distance rule, as it concerns both the location of wind turbines in relation to buildings (namely residential buildings or mixed-use buildings used for residential purposes) and environmentally-valuable areas (i.e. specific forms of nature conservation and forest promotional complexes ${ }^{25}$ ) and the location of buildings in relation to wind farms. The minimum distance to locate and build a wind farm is at least ten times the height of the turbine, measured from ground level to the turbine's highest point, including technical elements, especially the rotor and blades ${ }^{26}$ (i.e. total height of the turbine $\left.^{27}\right)$. However, it should be emphasised that this rule does not apply to works such as reconstruction, superstructure, extension, refurbishment, assembly or reconstruction ${ }^{28}$ of a residential building or a building with

23 See art. 42016 Act.

24 See more: art. 6 et seq. of the Act of 16 April 2004 on Nature Conservation (Official Journal of Laws 2018, item 1614, as amended, consolidated text).

25 To promote sustainable forest management and the protection of natural resources in forests, the Director-General may, by virtue of an Ordinance, establish Promotional Forest Complexes. Promotional Forest Complexes shall comprise forests administered by the State Forests, as well as forests under other forms of ownership, should their inclusion be requested by their owners. Promotional Forest Complexes shall be functional areas of ecological, educational and social importance, whose activity shall be set out in a single management and protection programme drawn up by the appropriate Director at a Regional Directorate of the State Forests. (see art. 13b of the Act of 28 September 1991 on Forests; Official Journal of Laws 2018, item 2129, as amended, consolidated text).

26 See: judgement of the Voivodeship Administrative Court in Poznań of 24 August 2017, II SA/Po 227/17, LEX nr 2373568 and judgement of the Voivodeship Administrative Court in Warsaw of 8 December 2017, VII SA/Wa 351/17, LEX nr 2496124.

27 See art. 4(1) of the 2016 Act.

28 Definitions of the terms have been included in the act of 7 July 1994 Construction Law (Official Journal of Laws 2018, item 1202, as amended, consolidated text; art. 3 point 6 , art. 3 point 7 a, art. 3 point 8 , art. 3 point 2 ). 
a residential function, which includes a housing function. The distance rule must be taken into account by public administration authorities in their decision making process ${ }^{29}$, including the adoption of zoning laws ${ }^{30}$ (i.a. land use plans or local zoning plans) ${ }^{31}$.

Unfortunately, the provisions referred to above drew considerable criticism, first of all, due to the fact that Poland has an extensive network of nature conservation forms, including in particular Nature 2000 areas. This means that the use of the fixed and inflexible measure of distance, established at ten times the height of the wind turbine, the number of possible locations basically goes down to zero ${ }^{32}$. Secondly, it is believed that so-called farmsteads, popular in rural areas, which came to have their definition in the case law of the Supreme Administrative Court, where they are defined as a group of buildings comprising a farmhouse and farm buildings, situated within one farmyard, do not sanction the location of wind turbines without infringement of the prohibitions laid down in the Act ${ }^{33}$.

Another crucial point to be discussed is the principle of locating ${ }^{34}$ a wind farm based on land use plans, which follows from art. 3 of the $2016 \mathrm{Act}^{35}$. This means that the location of wind farms cannot be based

29 The Legislator advised to take into consideration the distance rule when issuing decisions such as for example, planning permission, building permit, the environmental decision.

30 See art. 6 of the 2016 Act.

31 See more: Monika Przybylska, "Zasada odległościowa w procesie inwestycyjnym elektrowni wiatrowej i zabudowy mieszkaniowej a działania organów samorządowych”, The State and Law 4(2018):103; Monika Przybylska-Cząstkiewicz, "Planowanie przestrzenne w gminie po wejściu w życie ustawy z dnia 20 maja 2016 r. o inwestycjach w zakresie elektrowni wiatrowych", Casus 84(2017):15-20.

32 Marcin Makowski, "Ustawa o inwestycjach w zakresie elektrowni wiatrowych. Komentarz, Wprowadzenie”, legal status as of 20 September 2018, LEX.

33 Ibidem.

34 See more e.g.: Małgorzata Stahl, "Planowanie i zagospodarowanie przestrzenne", In: Prawo administracyjne materialne, ed. Zofia Duniewska, Barbara Jaworska-Dębska, Małgorzata Stahl, Warszawa: Wolters Kluwer, 2014, 507-524; Wojciech Szwajdler, "Miejscowy plan zagospodarowania przestrzennego gminy a studium uwarunkowań i kierunków zagospodarowania przestrzennego gminy”, Territorial Self-Government 5(2010):34-45; Aleksander Lipiński, "Miejscowy plan zagospodarowania przestrzennego jako instrument ochrony środowiska”, Studia Iuridica Agraria XXIV(2016):221-243.

35 See art. 6 of the 2016 Act. 
on planning permission ${ }^{36}$. More importantly, the distance rule should be taken into account not only when drawing up land use plans but also when developing local zoning plans ${ }^{37}$. This is extremely important as the study's arrangements are binding for commune authorities when drawing up local plans ${ }^{38}$. Nevertheless, it must be taken into account that the local zoning plan itself is not a universally binding $\operatorname{law}^{39}$ and does not shape the investor's legal situation, as it is not a local law act ${ }^{40}$.

However, it should be noted that unfortunately this regulation may contribute to a significant slowdown in the development of wind farms in Poland. Planning works are carried out on too small of a scale, which results from the preparation of local plans being optional in general ${ }^{41}$. In addition, the procedure for adopting both land use plans or local zoning plans is long-lasting, complicated and multi-staged, and also is not free from many flaws and shortcomings ${ }^{42}$.

36 See art. 4 item 2 point 1 i 2 of the Spatial Planning and Land Development Act of 27 March 2003 (Official Journal of Laws 2018, item 1945, as amended, consolidated text, further: p.p.l.d. Act).

37 See art. 6 point 1 of the 2016 Act.

38 See art. 9 item 4 of the p.p.l.d. Act.

39 See art. 9 item 5 of the p.p.l.d. Act.

40 Monika Przybylska, The 'distance principle'..., 105.

41 The obligation to draw up local plans results from several regulations. These are the following acts:

- of 7 May 1999 applying to the protection of the area of Nazi extermination camps (Official Journal of Laws 2015, item 2120; art. 5 item 1);

- of 28 July 2005 on Health Resort Medical Care, Health Resorts, Health Resort Protection Areas and Health Resort Gminas (Official Journal of Laws 2017, item 1056, as amended, consolidated text; art. 38b);

- of 10 July 2015 on the Military Property Agency (Official Journal of Laws 2017, item 1456, consolidated text; art. 98 item 2);

- of 3 July 2002 Air law (Official Journal of Laws 2018, item 1183, as amended, consolidated text; art. 55 item 9);

- of 23 July 2003 on the protection of monuments and the care of monuments (Official Journal of Laws 2018, item 2067, as amended, consolidated text; art. 16 item 6).

42 Extensive calculation of errors in local plans presents Aleksander Lipiński, "Miejscowy plan zagospodarowania przestrzennego jako źródło prawa”, Legal Problems of Mining and Environmental Protection 1(2017):43-49. 
Conclusions from the practical applications of the aforementioned regulations are regretfully not optimistic. The volatility and uncertainty of provisions of law, as well as their complexity, is not conducive to building investors' trust and to the development of the renewable energy sources sector. Furthermore, the 2016 Act put a strong halt to the development of wind farms, whose output has a significant share in the production of renewable energy in Poland ${ }^{43}$. This was also emphasised in the recent report by the Supreme Audit Office ${ }^{44}$. Regretfully, the conclusion that follows is that Poland will not fulfil one of its obligations spelled out in the Paris Agreement, namely increasing the share of renewable energy sources in the energy mix.

\section{CONCLUSIONS}

Summing up, Poland is yet to adopt legal instruments intended to implement provisions of the Paris Agreement. The only measures that have been introduced to-date are of an organisational nature, or measures utilising current legislation.

As included in our analysis, this activity is very often not sufficient enough and sometimes adopted provisions are contradictory to the aims of the Paris Agreement, like in the case of the 2016 Act. That is why the Polish legislator has to start work on future amendments of Polish law to

43 Filip Nawrot, "Budowa instalacji odnawialnych źródeł energii a planowanie przestrzenne”, Legal Problems of Mining and Environmental Protection 1(2017):71 et seq.

44 The conclusions from the above document are very worrying. As stated in the report: "Poland's achievement of the target of $15 \%$ of energy from renewable sources in total gross energy consumption in 2020 may be at risk. In 2016, this index slightly exceeded only 11 percent and was the lowest since 2013. As a result, Poland will probably face the necessity of statistical transfer of energy from RES from Member States that are in surplus of this energy. The costs of this transfer can reach up to PLN 8 billion. NIK indicates that the development of renewable energy in our country was negatively influenced by, among others: lack of consistent state policy towards renewable energy sources, delays in issuing regulations and lack of a stable and friendly legal environment ensuring security and predictability of RES investments, in particular in the electricity sector”. December 21, 2018 https://www.nik.gov.pl/najnowsze-informacje-o-wynikach-kontroli/zielona-energia-dostala-zadyszki.html. 
fully implement provisions of the Paris Agreement. However, there is no information about planned legislative activity in this area.

\section{REFERENCES:}

Dobrowolski, Grzegorz, Lipiński, Aleksander, Mikosz, Ryszard, Radecki, Gabriel. 2018. Gospodarowanie geologicznymi zasobami środowiska w świetle zasady zrównoważonego rozwoju. Zagadnienia prawne [Management of the geological resources in the light of the principle of sustainable development. Legal issues], Katowice: Wydawnictwo Uniwersytetu Śląskiego.

Dobrowolski, Grzegorz. 2014. "Prawne zasady podejmowania i prowadzenia działalności w zakresie bezpiecznego geologicznego składowania dwutlenku węgla" ["Legal rules for taking up and pursuit of the activity of safe geological storage of carbon dioxide"]. In: Prawna regulacja geologii i górnictwa w Polsce, Czechach i na Słowacji. Wybrane zagadnienia, ed. Dobrowolski Grzegorz, Radecki Gabriel. Katowice: Grupa Infomax.

Dobrowolski, Grzegorz, Radecki, Gabriel. 2016. In: “Zrównoważony rozwój jako czynnik determinujący prawne podstawy zarządzania geologicznymi zasobami środowiska" ["Sustainable development as a defining factor of management of geological resources”], ed. Dobrowolski Grzegorz. Katowice: Agencja Reklamowa TOP.

Dubiński, Józef, Wachowicz, Jan, Koteras, Aleksandra. 2010. "Podziemne składowanie dwutlenku węgla - możliwość wykorzystania technologii CCS w polskich uwarunkowaniach" ["Underground carbon dioxide storage - possibilities of using the CCS technology in Polish conditions"]. Górnictwo i Geologia 1.

Lipiński, Aleksander. 2016. "Komentarz do art. 1- 2 ustawy z dnia 9 czerwca 2011 r. Prawo geologiczne i górnicze" ["Commentary to the articles $1-2$ of the Act of 9 June 2011 Geological and mining law”]. Prawne problemy górnictwie i ochrony środowiska 1 [Legal Problems of Mining and Environmental Protection 1].

Lipiński, Aleksander. 2017. "Miejscowy plan zagospodarowania przestrzennego jako źródło prawa". "Legal Problems of Mining and Environmental Protection" 1:33-54.

Lipiński, Aleksander. 2016, "Miejscowy plan zagospodarowania przestrzennego jako instrument ochrony środowiska". "Studia Iuridica Agraria” XXIV:221-224.

Makowski, Marcin. 2018. "Ustawa o inwestycjach w zakresie elektrowni wiatrowych. Komentarz, Wprowadzenie”, legal status as of 20 September 2018, LEX. 
Nawrot, Filip. 2017. "Budowa instalacji odnawialnych źródeł energii a planowanie przestrzenne". "Legal Problems of Mining and Environmental Protection" 1:71-89.

Przybylska, Monika. 2018. "Zasada odległościowa w procesie inwestycyjnym elektrowni wiatrowej i zabudowy mieszkaniowej a działania organów samorządowych", "The State and Law" 4:3-28.

Przybylska-Cząstkiewicz, Monika. 2017. "Planowanie przestrzenne w gminie po wejściu w życie ustawy z dnia 20 maja 2016 r. o inwestycjach w zakresie elektrowni wiatrowych", "Casus" 84:15-20.

Stahl, Małgorzata. 2014. "Planowanie i zagospodarowanie przestrzenne”. In: Prawo administracyjne materialne, ed. Zofia Duniewska, Barbara Jaworska-Dębska, Małgorzata Stahl. 507-524. Warszawa: Wolters Kluwer.

Szwajdler, Wojciech. 2010. "Miejscowy plan zagospodarowania przestrzennego gminy a studium uwarunkowań i kierunków zagospodarowania przestrzennego gminy", "Territorial Self-Government" 5:34-35.

\section{Internet sources:}

http://projekty-rozwojowe.lasy.gov.pl/projekty-rozwojowe/-/asset_publisher /7PcENrBXIBZJ/content/lesne-gospodarstwa-weglowe July 29, 2019 http:// www.ebiomasa.pl/lesnictwo-news/item/2479-energa-wspiera-lesne-gospodarstwa-weglowe July 29, 2019

https://niezalezna.pl/206274-lesne-gospodarstwa-weglowe-swiat-powinien-sie-tym-zainteresowac July 29, 2019

https://oko.press/wunderwaffe-polskiej-ekologii-lesne-gospodarstwa-weglowe-nas-nie-uratuja/ July 29, 2019

http://www.mg.gov.pl/files/upload/12326/uzupełnienie\%20KPD_www.pdf July 29, 2019

https://www.gov.pl/web/energia/polityka-energetyczna-polski-do-2040-r- zapraszamy-do- konsultacji1 July 29, 2019

https://wysokienapiecie.pl/14959-polityka-energetyczna-2040-pobozne-zyczenia-w-sprawie-wegla-atomu/ July 29, 2019 